\title{
Gender Portrayal in Ekegusii Proverbs
}

\author{
Zipporah Kwamboka OTISO \\ University of Nairobi \\ Kenya
}

\begin{abstract}
This paper analyses the depiction of men and women in proverbs in Ekegusii, a Bantu language spoken in the western part of Kenya. The analyzed proverbs show the perceptions held by the society about males and females. There are proverbs that show what is considered to be the appropriate character for males and the value of males. Conversely, there are proverbs that show the character/ nature of females and the value of females. In addition, there are proverbs that make reference to males and females when giving advice and warnings. Besides this symmetrical representation, there are proverbs that make reference to both genders (in the same proverb) with the aim of underscoring gender differences, as there are those proverbs that make reference to both genders (in the same proverb) but with the aim of downplaying the gender differences. While it may generally appear that women are represented negatively in some proverbs, the women can use the negativity in those proverbs to their advantage. That is, the proverbs which would have been a tool of silencing and subjugating the women can instead serve as a form of emancipation for them.
\end{abstract}

\section{Introduction}

Proverbs in Ekegusii, like those in perhaps all other African languages, serve a number of purposes: to advise, to convey morals, to praise, to warn, to reproach and to encourage. A proverb may however serve more than one purpose at a time depending on the context of its use. Bosire-Ogechi (2006:124) observes about Ekegusii proverbs, that"There are proverbs which speak about [...] women and men [...]", although she does not give details of what it is that they say about men and what it is they say about women. This is what the present study aims to do.

It will group the proverbs into the following categories: a) those that present men's and women's character, such as Bamugamaaga ('Young men are fencing branches'), a proverb which portrays men as courageous and strong, and Abakungunabayanemenwayabasaririe ('Women are good except for their mouths'), which portrays women as careless talkers and quarrelsome; b) those that relate to responsible manhood and womanhood, such as Otarinang'ombemorokebana ('people should name children after he who has no cattle'), which shows that a responsible man is expected to own wealth, here in the form of cows, and Enda neroamaebi('The stomach is the love potion'), which suggests that a responsible woman is expected to cook well if she expects to be loved by her husband; c) those that relate to men's and women's value, such as Abamurabaomonto ne chinsarachireesaro('Somebody's sons are arrows in a quiver'), which shows how men, here represented by sons, are a security assurance, and Totogiamoisekekieni, motogiemwana('Do not praise a woman for her beauty; praise her for her child'), which shows that what matters in a woman is first of all her ability to give birth; d) those that give advice revolving around either the man or the woman, such as Eeron'eyabagaka('The sitting room is for men'), which suggests that only men are allowed in the sitting room, and Omwananoyobwoomokungu ('A child belongs to a woman'); e) those that give warnings revolving around the man or the woman, such as Moiboriominonkerechakereenyasi ('Your co-wife is a devil on the wall'), which warns about the challenges, on the part of the woman, of sharing a husband in a polygamous marriage; f) those that emphasize gender differences, such asOmosachaasache $n$ ' omokunguakunge('Let the husband look for/gather wealth and let the wife take care of it'), which delimits either gender's role; and g) those that downplay gender differences, such as Nachieabekeremaoyoneretataoyonere baba ('Even if he/she is lame, this is my father and this is my mother'), which calls for the respect of either parent irrespective of their gender.

From a detailed discussion and illustration of the categories above, the paper will provide solid ground on which to (potentially) appraise Schipper's (1991: 1) definition of proverbs as “... short pithy sayings, ingenuously embodying an admitted truth or common belief." But before picking up each category on its own, the paper will first define the various Ekegusii terms around which the various proverbs revolve.

\subsection{The terminology used in Ekegusii proverbs}

The Ekegusii terms for a man and which are used in proverbs are: omosacha or omogaka.The term 'omosacha' is not just a referent to a specific gender but it is also a marker of a gender role derived from the verb "gosacha", "to look for / 
gather wealth' (Otiso 2017:65). The term omogakaon the other hand is a reference term and does not carry gender undertones. These two terms also translate to 'man/husband', which makes them synonyms in some sense.

However, for the young boys/men, the termomoisia, 'lad, usually uncircumcised', a term which is sometimes considered an abuse, and the termomomura, 'a young circumcised man', are used. The criterion for the reference terms forlad (omoisia), for young man (omomura), and for adult man (omogaka)is age-basedwhereasthe reference for $a$ responsible husband/man (omosacha) is role-based. The proverbs used in reference to males mainly use any of the four terms: omoisia(itsshortened form is moisia and its plural form abaisia), omomura (and its plural abamura), omogaka(its shortened form is bagaka while its plural form isabagaka), or omosacha (its shortened form is mosachaand its plural abasacha).It is important to note that the term omonto (a person) is also usually interpreted to have a male referent. In addition, if in the proverb a child is talking about his/her father, then the term tata (father) is used while if it is another person talking about a child's father then the term ise ', 'his/her father', is used. Men are also represented using animal metaphors such as eeri, a bull, and chinchoke,shortened to nchonke, bees. In some instances, males are referred to by proper names (given to males) such as Mokaya.

On the other hand, the terms used for adult women are: omosubati, omokunguomorugi, andomongina. Omosubati refers to a young lady of marriageable age or newly married, with relatively young children. Omokungu,the opposite of omosacha, is derived from the verb gokunga, which means 'to take care of (property)', and translates to a wife, although it can also refer to a woman in general. In the latter meaning, it tends to have the same meaning as omongina, which is an elderly woman. A wife is sometimes referred to as omorugi, which translates to 'one who cooks.'Omongina is the opposite of omogaka. The terms for young girls are egesagane and omoiseke. Egesagane is a small girl, from birth to around ten years. Although circumcision has been outlawed, egesagane refers to an uncircumcised girl and is considered a term of abuse. Omoiseke on the other hand is a mature and 'circumcised' girl. The traditional term used by children to refer to their mother is $b a b a^{2}$ (although mama, a borrowingfrom Kiswahili, is now used more frequently). If one is talking about somebody's mother, then the term $n$ gina $^{3}$ (his/her mother) is used. The terms that are used in proverbs that make mention of women are: omoiseke (and the plural abaiseke), omokungu (and its plural abakungu), omorugi, baba and ngina, which is sometimes realized as engina.Nevertheless, women are also metaphorically compared to egesicha, (shortened to gesicha, a flower). When reference is made to both men and women, the metaphor Nyang'era ${ }^{4}$ and esese (a dog) are used.

\section{Men and women in Ekegusii Proverbs}

\subsection{Proverbs that relate to men's and women'scharacter}

There are proverbsthat show the behaviourexpected of the males:

(1) Eeritiyanakwanamarara('A bull never bellows while lying down')

(2) Mosachairooka('A man is an irooka, a type of perennial shrub')

(3) Omomuraotanyagotaranigoagokagang'ansobookabokorugwabwayia('An untravelled young man thinks that it is only in his own homestead where the "ugali" gets well cooked')

(4) Turetietari kina mbamuraetabwati/ ekenyorogetarin'ebina, naabamurabataiyo('A locality that has no legal disputes has no young men')

The first proverb reveals how men are socialized towards courage even in times of adversity. Likening a man to a bull which does not bellow while lying down implies that a man is expected to show courage at all times,including times of sickness. According to one informant for the present paper,even when a man is sick, he should not allow visitors walk to his bedroom. Instead, he should make an effort to rise up and meet with them in the living room. A bull bellows when it is in an upright position and usually does this while charging at its enemy. So just like the bulls, men are expected to be ready to defend not only their family but also the community when theneed arises. Proverb (2) compares a man to a perennial shrub, which rejuvenates back to life quickly after being cut. The proverb is both a pointer to the expected enduring character of males andan encouragement to them. Since it is omosacha, a man, who 'gathers

\footnotetext{
${ }^{1}$ If the child in question is present so that the reference is in second person then the term iso(your father) is used.

${ }^{2}$ Although this form is identical to the Kiswahili term for 'father', the sound in this term is a bilabial fricative and not a bilabial plosive as in Kiswahili.

${ }^{3}$ However, if the child in question is present so that reference is in the second person, then the term nyoko(your mother) is used. However, this term can also be used as an abuse term and because of this the phrase mama omino(your mother, with the term mama, for "mother" being a borrowed term from Kiswahili) is more often used.

${ }^{4}$ This is a term derived from eng'era, a buffalo. Cows that look like a buffalo, especially in their skin colour, are usually called Nyang'era.
} 
wealth', it is likely that he may incur losses in his wealth gathering endeavours. Men are however encouraged not to give up since, just like the irooka shrub, they can make profit after a loss.

Men are therefore not expected to resign to challenges but tobe resilient even in the face of various kinds of misfortunes. Proverb (3) can be considered as an indicator of the territory of the men outside the homestead. Due to their role as the 'wealth gatherers', they are expected to travel more widely than the women. An untravelled man is thus ridiculed through this proverb. The proverb alludes to ugali, $^{5}$, which is the staple food in the community, to express this. While there is almost no variation in the way ugaliis cooked, men are nevertheless expected to travel and have different experiences. Young men who think that it is only their mothers who know how to cook should not be surprised to learn that people in other homesteads know how to cook too. Men should not be contented with their familiar surroundings, including the familiar ways of gathering wealth. They should, instead, find other ways of 'gathering wealth' or else seek advice from others so that they more knowledgeable.

Proverb (4) suggests that lack of disputes in any locality is not the norm as young men are expected to behave in a somewhat erratic way. Such behaviour is likely to result in disputes which will end up at the council of elders (comprised only of men). It is surprising that although the community highly upholds good conduct, it seems to allow some leeway for misbehaviour. However, according to two informants, since men had the role of gosacha(looking for/gathering wealth), they would occasionally get into disputes while carrying out this duty. Such disputes were thus expected and their absence was the non-standard case. A totally different behavior is expected of women, though, as reflected in the proverb: Riomana ria mokungutirianakoirwatureti ('A woman's quarrel is never presented before a council of elders'). While men's disagreements are considered as ekina, a legal dispute, women's disagreements are considered as riomana, quarrels. Although quarrels may be equally serious, they are not considered serious enough, to warrant a hearing by the elders.

The proverbs that show the nature/character of women are:

(5) Abakungunabayanemenwayabasaririe('Women are good except for their mouths')

(6)Riomana ria mokungutirianakoirwaturetior eriomanari' omokungutiririkoirwakegambero ('A woman's quarrel is never presented before a council of elders')

(7) Oyogambeireomokunguogambeire ne chimbebachireamagachi('The one who has mastered how to manage [control] a wife has also managed to control the rats which are on the rafters')

(8) Yamokungu /ya 'mokunguterikoriegwakeu ('One cannot cut the belly meat from the one belonging to a woman')

(9) Nyamayamokungutiyanakobutorwakeu('The belly meat is never eaten or cut from a slaughtered animal belonging to a woman')

(10) Abakungutibanagotogiaondeotangoimbatogetienyamani('Women have never praised anyone; otherwise they would have praised the one who fed them on liver').

Proverb (5) expresses the perception that women are good except for their mouths. Women are seemingly not good orators possibly because they are not careful in the choice of their words or they are generally not good at keeping secrets. This may explain why they do not qualify to sit on the council of elders. This contrasts with one proverb on men: Aseabagaka bare nganatirianagosareka ('Nothing goes wrong where there are men'). While women are likely to cause disagreement due to their mouths, men are considered as having good oratory skills and can thus solve any disputes. Although proverb (6) looks like a piece of advice to men, it has nuances of how women are to be understood. A woman's quarrel is never presented before a council of elders probably because it is insignificant for their hearing. However, it can also be interpreted to mean that women's quarrels are too frequent and therefore are best be handled at home or are to be ignored.

Similarly, the community seems to view women as difficult to control and likens themto rats on the rafters. Proverb (7) may too be an encouragement to men not to be distressed when their wives prove problematic. Just like rats that move unpredictably from one rafter to another, so toocan women be erratic. Although proverbs (8) and (9) have differences in some lexical choices, they communicate the same message and can therefore be discussed as one proverb. It was common practice that once a butcher (who were and are men) hadslaughtered an animal, he would cut a piece of meat from its innards to taste. However, if the animal belonged to a woman, she would not allow him to do this. Women are therefore considered to be so stingy that they would not surrender even what was considered a conventional entitlement to a butcher. The proverb however serves as an encouragement to men to work hard and not rely on what their wives own. Proverb (10) on the other hand has its origin in a story of a man who wanted to impress his wives by supplying

\footnotetext{
${ }^{5}$ Although the proverb does not overtly mention ugali, this is the only type of food that native speakers will think of in such a context. This is because this is the only type of food that is prepared by the process of korugwa. 
them with game meat regularly. The women however had complaints about the meat, such as the fact that it was too tough or was tasteless. The man then decided to take them liver meat ${ }^{6}$, which is not only delicious but also pricy.

But not eventhe liver meat rendered them appreciative, making women to be perceived as ungrateful in spite of the efforts madeby men to please them.

One notable observation can be madefrom the proverbs discussed above: while the proverbs about men show some socialization towards some character traits, those about women do not present any socialization towards a trait but rather information about what appears to be their nature. Mumby and Clair (1997: 182) suggest that "Organizations and institutions are not seen as social collectives where shared meaning is produced but as sites of struggle where different groups compete the social reality." In the context of this argument, it can be presumed that the women who appear to have some negative portrayal such as being mean and having bad mouths (poor oratory skills) can actually contest against any injustice by taking advantage of their negative portrayal. For instance, proverb (6) which points out that a woman's quarrel is never presented before a council of elders, can permit women to be quarrelsome since they know that their quarrels will not be discussed outside their homesteads. Similarly, proverbs (8) and (9) which present women as being tight-fisted actuallygives women the right to be stingy with what they consider as their property. They can refuse to share their possessions and no one, including their husbands, can force them to surrender their ownership.

\subsection{Proverbs that relate toresponsible manhood and womanhood}

There are proverbs that relate to responsible manhood and husband hood:

(11) Montombantonang'ombe ('A person is people and cows')

(12) Otarinang'ombemorokebana ('People should name children after he who has no cattle')

(13)Omosachaomuyanoyokoringankundikagosoamochiemogokoosaranyomba('A good husband is the one who comes home with something hidden in his fist so that his arrival brings joy to his homestead').

Proverb (11) shows that a man is viewed as 'a person', who should own/possess'people' and 'cows'. The 'people' in this context is understood to refer to 'a wife/wives and children'. A responsible man should have 'cows', which are necessary in dowry payment, since this is the only way that he will be able to marry/acquire a wife for himself. Although women (and children) are seen as one of a man's possessions, they are important in defining 'a person' or 'a man'.This proverb shows the importance of a wife in 'making a man complete'. Proverb (11) relates to (12) which reinforces the importance of cows. This saying is not a condemnation of poverty but a warning that a man who does not own resources which would enable him to marry may never do so. Relatives of such a man can therefore name ${ }^{8}$ children after him. Naming children after a dead kinsman is a sure way of ensuring that their 'name' lives on. For proverb (13), a responsible husband provides for his family since he does not go to his home empty-handed.Although what the man should take back home is not explicitly stated, it is nevertheless something that is either necessary or a delicacy such that it creates a mood of joy in the homestead. This view about men emphasizes their role as "wealth gatherers".

There are also proverbsthat imply responsible womanhood:

(14)Omokungusiomiasiomiangaiakomanyabwarugeirwegosembokegosembwamwana? ('How will a woman who roams from place to place (or homestead to homestead) know where the ugali has been cooked and whether it is just a little meant for the baby?')

(15)Enda neroamaebi('The stomach is the love potion').

Proverbs (14) and (15) relate to women's duty as abarugi (plural of omorugi), 'the ones who cook'. A good woman is one who keeps to her homestead so that she manages it well. A woman who roams from place to place does not know what relates to her core duties such as knowledge of where ugali has been cooked. The word 'where' here is an instrumental, not a locative. In addition, she does not know how much food has been prepared and whether it is sufficient for the whole family or not. Proverb (15) was created from the setting of a traditional society which allowed polygamy, forcing wives to compete for the attention of their husbands. One sure way in which a wife would catch her husband's attention was through preparing sumptuous meals for him. A good meal is likened to a love potion as a way of encouraging women to take their duty seriously. These two proverbs that show the responsible behaviour expectedof women emphasize the latter's role as abarugi, the ones who cook.

\footnotetext{
${ }^{6}$ This made the man be nicknamed nyamani, derived from rini, meaning liver, (the plural of which is amani)

${ }^{7}$ Omonto, a person is usually interpreted to refer to a man although it is supposed to be a generic term.

${ }^{8}$ Naming children after people who are alive is not the norm since naming is done after dead kinsman. A poor man is thus as good as dead.
} 


\subsection{Proverbs that relate to men's and women'svalue}

Men's value stems from the roles that they take up in their family or the larger society. For instance, it is men's role to defend the family and the community. This explains their representation in the following proverbs:

(16)Abamurabaomonto ne chinsarachireesaro ('Somebody's sons are arrows in a quiver').

(17) Bamuramaaga('Young men are fencing branches')

(18) Omogaka ore bwoye ne ritiirorireenyasi ('A man who is in his homestead is a pillar on the wall')

(19) Omomura ore sobo ne rirubinyamong'eto ('A young man who is in his home is a mature/big cobra')

(20) Nguru chia momura 'nchoguegwatimbara ('A young man's energy is like an elephant which splits trees into firewood')

In proverb (16), sons (young men) are metaphorically seen as arrows which are used in warfare. Arrows are common traditional weapons. By comparison, it is young men who used to take part in combat when the need arose. The young men are thus seen as arrows since any homestead that has them is assured of protection in case of attacks and conflicts. Proverb (17) is closely related to the preceding one and compares young men to fencing branches. The young men are metaphorically likened to fencing branches which are used to demarcate boundaries. They are thus valuable because they are assumed to protect their families from any would-be intruders in the same way that fencing branches keep away any unwanted intruder. Proverb(18) shows the confidence that men provide by their presence in their homes. The origin of this proverb is the traditional houses that had pillars inthe wall to reinforce the house. A house that had pillars that were well fixed was not in danger of collapsing. The proverb hints at the way a man offers security because his family need not worry about lack of basic necessities like food. They also need not be concerned about external attacks since the man doubles up as a warrior. And, if any dispute were to arise they would be assured that the man would handle it appropriately and fearlessly.

Proverb (19) metaphorically likens a young man to a mature/big cobra. Although snakes are rare in the community, a cobra is fearedand when it is presented as a mature one, then the dread of it gets intensified (Otiso 2016b:173). So a young manis likened to a mature cobra, he is expected to be able to scare away any invaders. Offering such a kind of defence for himself and his family when necessary is valuable. Proverb (20) talks about young men's literal physical strength which is exaggeratedly likened to that of elephants splitting big trees to firewood. Other than providing security for the family, young men are also valued for their physical strength which is useful in various types of manual work.

While the value of men is related to security and strength, the value of women is connected to their biological function of child-bearing. Children are an integral part of the society and for a woman not to be able to bear them used to call for various interventions including polygamy and women 'marrying' other women ${ }^{9}$. The roleof child-bearing is entrusted more to the women than to the men. The proverbs that relate to this value are:

(21)Totogiamoisekekieni, motogiemwana ('Do not praise a woman for her beauty; praise her for her child, that is, her ability to give birth')

(22)Toenenabunamorogi ore nabamura/takong'eng'eriabunamokungumorogi ore nabamura('Don't be stubborn/rude like a [woman] witch who has sons')

(23) Okoiboranokuyagwakoreteomokungumonyakanting'ana/eting'ana('Giving birth is good because it made the promiscuous/despised woman to be a queen')

As proverb (21) reveals, a woman is to be praised more for her ability to bear children and not just for her looks. A good-looking girl who is barren finds herself at a disadvantagesince this increases the chance of her husband marrying another 'fertile'wife. While beauty is appreciated, the ability to bear children is considered of greater importance. Proverb (22) on the other hand points out two unacceptable traits: stubbornness/rudeness and witchcraft. Women are not expected to be rude. However, such rudewomen can still feel safe if they have sons who can protect them. It is women who are assumed to practise witchcraft, a vice punishable by lynching. But if a witch has sonsthen other people will fear the latter's wrath and will not harm her. Proverb (23) shows how child- bearing made a despised/ promiscuous woman a queen. Although there are no queens among the Abagusii, the community knows very well that queens are dignified women. Children can therefore save their mothers from disgrace when they become successful.

\subsection{Proverbs that relate to givingadvice by referring to men and women}

There are proverbs thatmention males when giving pieces of advice:

(24) Eeron'eyabagaka('The sitting room is for men')

\footnotetext{
${ }^{9}$ This practice allowed a barren woman or one who had no sons to 'marry' another woman who already had children out of wedlock. She would bear other children with another man but all her children were recognized as 'grandchildren' of the woman who had 'married' her, since the woman supposedly married a 'daughter-in-law'. 
(25) Kaaamandegere name Getembeotarinamomuratakoyaa ('In future, mushrooms will sprout at Getembe [modern day Kisii town] but those without sons will not uproot [harvest] them')

(26)Mokayaoireenaigokengeka/ bogeka('Mokaya, direct the arrow to the wrong direction/sideways')

Proverb (24) shows thatthe men's territory in a house is the sitting room. Stating that the sitting room is a preserve for men, makes one to question why women were excluded from this space. To begin with, this room had a section reserved for ensiongo, a beer pot. Although women were the ones who prepared the beer, they were not allowed to drink it, safe for when they were quite elderly. Beer was a leisure pastime for men but was also drunk by themas theydiscussed important family or societal matters. The men therefore had the role of living lives of integrity so that they could be admitted to the discussion of weighty family and societal matters. The term abagaka (plural of omogaka) refers to 'elderly men' who were presumed to havewisdom and experience on many matters. Although elderly women may toohave gathered experience over their years, they did not get 'admitted' to the sitting room. This proverb also disqualifies young and inexperienced men from occupying space in the sitting room. The proverb is however contextualized in various settings to communicate that various duties should be handled by those mandated to do them. The specialization of roles based on gender, age and experience helps the society to function well by ensuring thatinterference is minimized.Proverb (25) has its origin in a prophecy that was given by Sakawa, a renowned Gusii prophet. He likened the sprouting of mushrooms to prosperity and young boys to education. This prophecy, which is accepted as a proverb, views intellectual prowess as a men's attribute. The use of the proverb in wider contexts is an advice that people should embrace western education if they have to get its benefits such as white-collar jobs.

Proverb (26) originates from the duty of 'tapping' blood from a cow. This was done by using enaigo, 'a special type of arrow'. An expert, symbolized by Mokaya, a male name, would prick a cow's vein to allow just enough blood to ooze out. This would not harm the cow but occasionally a shrewd blood tapper would misdirect the arrow. The shrewd act would lead to the death of thecow, thereby benefitting the men with meat instead of just blood. Though with time deceptive ways of the blood tappers were discovered and the perpetrators punished, such a behaviour was not expected to be condoned. The contextual use of this proverb is the giving of a ruling about cases that involve vulnerable people such as orphans and widows. Citing the proverb in such contexts serves the purpose of encouraging the elders to 'bend' justice so that the offender is treated with some leniency. It can therefore be argued that what started as a shrewd behaviour has ended up being justified and accepted in modern times.

There are also proverbs that refer to females in giving advice. These are:

(27) Mokungunke'koritokomanyabuyabwayeotaraikansanse ('A wife is the bottom of a pot; you never know its importance before you sit down')

(28) Omoisekeesang'ondeomonyeneemorinamoroche ('A beautiful girl with big thighs has been noticed by the owner of the calf')

(29)Asegesichageseerakerenchokensamisitichianakomochaaroro ('You cannot fail to findbees where there is a beautiful flower')

(30) Omoiseke ore sobonsigitietaratwata ("An unmarried girl who is still in her home is a ewe that has not calved [given birth]')

\section{(31) omwananoyobwoomokungu ('A child belongs to a woman')}

Proverb (27) suggests that women may not be on the forefront in duties of decision-makingbut they are nevertheless indispensable. They are compared to the bottom of a pot, which is rarely visible because this is the part that the pot sits on.The advice given in the proverbis that while some roles played by women may not be visible enough,their impact will be felt, should they go missing. Such roles may include household chores best performed by women, such as cooking and nursing children.Proverbs (28), (29) and (30)relate to a woman's beauty. Proverb(28) proposes that beautiful girls, with big thighs, get noticed and booked for marriage early by wealthy men. ${ }^{10}$ Proverb (29), on the other hand, likens a beautiful girl to a flower, while men are likened to bees. Justthe same way that bees look for nectar from flowers so do men flock around beautiful girls. Proverbs (28) and (29) give pieces of advice for both men and women. For the men, the advice is that they should expect some competition for beautiful girls from fellow men. For the women, the advice is that, they should expect men to take notice of them especially if they are beautiful.

Proverb (30) likens a young lady to a ewe that has not given birth. Such a girl is to be viewed differently from a woman. Both men and women are thus advised that they should expect women to change, especially physically, with child bearing. A woman should not be condemned because of biologically-relatedchanges. Proverb (31) asserts that a child belongs to a woman. This proverb can receive three interpretations: firstly, it is only the mother who knows the biological father of the child.

\footnotetext{
${ }^{10}$ Being wealthy is implied by mention of 'the owner of the calf'.Cows are usually given as dowry for marriage.
} 
Secondly, if a child does not become successful later in life, or if he/she becomes undisciplined, men tend to distance themselves from him/her byclaiming that the child belongs to the mother. The case will be different if the childsucceeds.

Thirdly, the proverb implies that children will be in support of their mothers in case of a disagreements between the parents. It is presumed that children have a stronger attachment to their mothers though they get their identity from their father's name.

\subsection{Proverbs that refer to males and females in giving warnings}

There are proverbs that refer to males in warning againstdoing things out anger and being too trusting. These are:

(32) Toiteramoisiaenkundi, $n$ ' egesakuogosiri ('Do not punch a boy; that could terminate a clan')

(33) Esemoiyarieteeyende ('A semo ${ }^{11}$ defrauded another semo')

Proverb (32) warns people against punching a boy since this may affect his reproductive organs thereby terminating his chances of siring a child and by extension a clan. Men's virility isimportant because it is harder to handle men's impotence than women's infertility. If a wife was assumed to be barren, her husband would marry another wife to sire children for him. It would however not be easy to solve a case of a husband's sterility. The wider contextual use of the proverb is that one should not do anything out of anger since this may lead to irreversible consequences. Proverb (33) talks about semo, men who have married sisters. Such men are supposed to treat each other with respect, but the proverb shows thatthere could occasionally be cases of deception between them. The warning in the proverb is that people should not be quick to trust anyone.

There are also proverbs that refer to women in issuing warnings:

(34) Mokungutanagotomwa (gotura) sira / omokungutarigotomwakobwatiaesira ("A woman is never sent to reclaim a debt')

(35) Moibobiominonkerechakereenyasi ('Your co-wife is a devil on the wall')

(36)Ritingembotukorikong'anya ('The escapee wife/ estranged wife/ divorcee/ concubine/ mistress ${ }^{12}$ normally deserts the homestead at night')

(37) Eseseenkunguiyaireteeseseetwonibogere/ seseeaberiyarusetietwonibogere ('A female dog took a male dog to Luo land/ a female dog brought a male dog from Luo land')

(38) Tosekigwaigogiokabworokieomorugioononyan'amagegu ('Do not be made to laugh so hardtill you show your wife all the molars')

Proverb (34) is about one thing that women should not do: to be sent to reclaim a debt. As already pointed out in section 3.1, women are perceived to have poor oratory skills and may talk in an offending manner to the debtor. This may make the debtor not to pay back whatever is owed. However, the proverb alsoserves to protect women from any unpleasant exchanges that may arise from negotiation with a debtor. Proverb (35) shows that the communitypractised polygamy and it was therefore not strange that co-wives usually quarrelled with each other. This sour relationship between them makes one's co-wife be likened to a devil on the wall.The devil connotes evil and the use of it being on the wall shows how it is a constant problem. Women are thus warned that they should not expect good relations with their co-wives. The women who found themselves in a polygamous marriage had therefore to contend with the unpleasant relationships in those families. Proverb (36) sends a warning to men that ritinge, an escapee wife, abandons her 'home' unexpectedly. Such a wife runs away at night probably because of shame. Andleaving at such a time causes inconvenience as she leaves when her services, such as preparing the family's supper, are needed most. Men are therefore warned to be more considerate of their legal wives thanthe escapee wives. Proverb (37) warns men about the seductive power of women though both men and women are likened to dogs. While there is very little intermarriage between the Abagusii and the Luos, the proverb is placed in the context of seduction which may lead to marriage. Itwarns people that there is need to be careful with their friends, as a friend can make one do inconceivable and regrettable things. Proverb (38) literally warns a man about laughing so hard that he shows his wife his molars. The hearty laughter by a man is symbolic of getting excited to a point of making unrealistic promises or saying things that one shouldn't have ordinarily said. The proverb seems to suggest that women cannot be wholly trusted and men should be cautious about what information they disclose to them.

\subsection{Proverbs that emphasize gender differences}

\footnotetext{
${ }^{11}$ Semo, men who have married sisters, are supposed to respect and treat each other well.

${ }^{12}$ Ritingetypically refers to a woman who deserts her marital home so as to get 'married' elsewhere. She is usually not considered as a legal wife in the second relationship.
} 
There are proverbs that underscore the distinction between males and females, based on their respective gender roles. These are:

(39) Omosachaasache n' omokunguakunge ('Let the husband look for/gather wealth and let the wife take care of it') (40) Abamuranaabaisikonaabaiseken'abanyomba ('Boys belong to the outside and girls belong to the house')

(41) Basachambaniberanianabakungumbaiborerani ('Men help one another to gather wealth while women help one another to 'beget' children')

(42)Mosachakobwatandainchara; mokungukobwatandaimayianda ('A man clutches his stomach as a sign of hunger; a woman clutches her stomach as a sign of sorrow')

Proverb (39) states that men should 'gather wealth' while women should 'take care of the wealth'. Recording these roles in a proverb ensures asmooth flow of family activities besides helping to decide on the person who might be on the wrong should a conflict that relates to gender roles arise. Proverb (40) relates to the gender roles by showing the areas of operation for the males and the females. The roles of 'wealth-gathering' usually force the males to work outside the homestead while the role of women of 'taking care of wealth' is likely to centre on the homestead. Proverb (41) implies that as men engage in their roles, they can help one another to gather wealth while women help one another to 'beget' children. For instance, if one man wants to pay dowry but does not have enough 'cows', he can request another man to help him with some, thereby helping one another to 'gather wealth'. The idea that womenhelp one another in 'begetting' children can be explained thus: ifa man's first wife gave birth to a daughter as herfirst born childwhile the second wife gavebirth to a son as her first born, the custom was that 'cows' given as dowryfor the marriage of the daughter of the first wife would be used to pay dowry for the son of the second wife. Women, especially co-wives, benefit from one another from their step-children while men can benefit from the wealth of other men. Proverb (42) reflects how men and women react differently to situations. When a woman is in distress, such as that arising fromthe loss of a child, she clutches her tummy. Men are however expected to exercise restraint even in difficult times and not clutch their tummies. Clutching a tummy out of hunger is a normal reaction but clutching it out of sorrow would be a sign of weakness.Men are thus expected to be a source of encouragement at all times. Women can express their emotions freely but men are expected to exercise restraint.

\subsection{Proverbs that downplay gender differences}

Though there are proverbs that relate to gender differences, there are others that present males and females as equals. The latter proverbs are related to how children view their parents. While the Gusiisociety assesses males and females differently and has different expectations for them, to children both parents are equally important. The proverbs in question are:

(43) Nachieabekeremaoyoneretataoyonere baba ('Even if he/she is lame, this is my father and this is my mother')

(44) Etagwetieng'inanekogwaise ('If it doesn't resemble the mother, then it resembles the father')

(45) Nyang'erandotunginamoriyayendotungi ('The buffalo-like $\operatorname{cow}^{13}$ has 'a trait' and its calf also has 'the trait')

(46) Tata na baba bandereretekwankamenya (My father and my mother took care of me in their bosom so that I survived)

(47) Tata na baba n' abaya n' ebintobikobora ('Both my father and my mother are good, but there are no 'things'/resources').

It is evident from proverb (43) that children do not mind the physical disabilities that their parents might have. The only relevant aspect to children is the fact that they are their parents, all other weaknesses notwithstanding. Proverbs (44) and (45) show that children will either take aftertheir father or their mother. Besides inheriting the parents' physical features, the children also inherit their parents' mannerisms. Proverb (46) metaphorically refers to the parents and thechildren as a cow that is christened Nyang'era because it looks like eng'era, 'a buffalo'. Whatever trait that the parents have is likely to be inherent in theirchildren. Proverbs (46) and (47) express appreciation for the roles that both parents played in raising up their children. Proverb (47) adds that if children were to extend help to and appreciation for their parents, they would do so but the only challenge that the children face is lack of 'resources' to express appreciation that would measure up to what the parents did for them.

\section{Conclusion}

This paper has shown what men's and women's character, responsibilities and values are expected to be in Gusii culture. It has also warned them about certain dangers to family unity and marital harmony and given them advice on how to avert such dangers. It has done all that through Ekegusii proverbs, which are thus embodiments of "the social

\footnotetext{
${ }^{13}$ The name Nyang'era which is given to some type of cows, is derived from 'eng'era', 'a buffalo'.
} 
roles and identities of the men and women who speak [the Ekegusii language]", to borrow words from Wardhaugh and Fuller (2015: 311).

More specifically, Ekegusii proverbs were shown to portray men as strong (in the sense that they can defend their families), as long-suffering and well-travelled, and women also as strong (in the sense that they bear children and thus ensure the continuity of the family lineage), but also as ungrateful and careless in speech, among other traits. They were also shown to advise men to amass possessions which will enable them to marry and have children, and to advise women that they should manage the homestead well, starting with feeding their husbands well. But some of the proverbs discussed assign specific roles to men and women, and while some of them emphasize the gender differences reflected in these respective roles, others show that both men and women are valuable members of society, thus implying that their roles are complementary.

\section{References}

Bosire-Ogechi, E. 2006. Ekegusii Folklore. In Akama, J.S. and J.S. Maxon, R. (eds). Ethnography of the Gusii of Western Kenya: A vanishing Cultural Heritage. New York: Edwin Mellen Press, pp 119-137

Hyatt, David. 2005. Time for a Change: A Critical Discourse Analysis of Synchronic Context with Diachronic Relevance. Discourse and Society, 16 (40): 515-534

Otiso Zipporah K.2016a. Examining the Indigenous Wisdom in Ekegusii Proverbs. Journal of Language and Linguistics: Special Volume on Mother-Tongue Issues 5, pp. 115-129. University of Nairobi

2016b. Gender Construction, Representation, Contestation and Maintenance: A case study of Ekegusii Discourse. Unpublished PhD Dissertation: University of Nairobi

2017. Gender Identity through the Ekegusii Naming System. The University of Nairobi Journal of Language and Linguistics Vol. 6: 64- 82

Mandi, Joseph W. (2012) Chinkwana chi'Abagusii: Emebayeno, Emerabaro, EkegusiikiaIme: unpublished manuscript.

Mumby, Dennis K. and Robin P. Clair. (1997) 'Organizational Discourse'. In Van Dijk, T.A. (ed.) Discourse as Social Interaction, London: Sage Publications, pp. 181-205.

Schipper, Mineke. 1991. Source of all Evil: African Proverbs and Sayings on Women. London: Allison and Busby books

Wardhaugh, Ronald and Janet M. Fuller. 2015. An Introduction to Sociolinguistics, $7^{\text {th }}$ edn. Malden: Wiley-Blackwell. 